\title{
The Determinants of Successful Nation-building: Macro- sociological Political Modernization and Political Alliance Structures
}

\author{
Harris Mylonas (D) \\ George Washington University, Washington D.C., USA \\ Corresponding author. Email: mylonas@gwu.edu
}

Nation Building: Why Some Countries Come Together While Others Fall Apart, by Andreas Wimmer, Princeton, Princeton University Press, 2018, 376p. \$39.95 (cloth), ISBN 9780691177380 , \$27.95 (paper back), ISBN 9780691202945.

Andreas Wimmer's Nation Building is a terrific book, an instant classic comparable to Karl Deutsch's Nationalism and Social Communication (1953) or Ernest Gellner's Nations and Nationalism (1983). The empirical puzzle that motivates his work is right there in the title-why some states, like Somalia or Belgium, fall apart or fail to unite, while others, like Botswana or Switzerland, come together and remain that way, seemingly without regard to oft-cited factors such as democracy, development, or ancestral/ethnic heterogeneity. The broader research question that naturally flows from the puzzle is this: why does nation-building succeed in some cases but not in others?

For Wimmer, successful nation-building manifests itself in having forged "political ties between citizens and the state that reach across ethnic divides and integrate ethnic majorities and minorities into an inclusive power arrangement" (1). He operationalizes successful nation-building through the degree of ethnopolitical inclusion in a country's power structures and citizens' identification with their nation-state. The crux of the argument is that state centralization in the $19^{\text {th }}$ century-in turn a product of warfighting, in Europe, and topography facilitating state control "where peasants could not escape" (16), elsewhere, combined with population density high enough to sustain a nonproductive political elite at the end of the Middle Ages-facilitated the conditions for the linguistic homogenization of populations and the construction of central governments able to provide public goods. These two factors, along with the presence of civic society that spans ancestral/ethnic divisions, lead to successful nation-building.

The book unfolds like a detective story. Wimmer begins with three chapters that illustrate the "proximate" causes of successful nation-building by studying the historical development of three pairs of states. First, Switzerland and Belgium illustrate the importance of voluntary organizations. He then turns to Botswana and Somalia to explain the centrality of public goods provision. Finally, China and Russia serve as cases with varying levels of linguistic integration, or communicative homogeneity, that resulted in divergent outcomes. Across these case comparisons, Wimmer highlights how the historical interaction between a state's institutional and associational forms of political cohesion shapes nation-building outcomes. Similar proximate mechanisms have been underscored by other scholars such as Scott Straus (2015), who emphasizes the alignment between state and society as a buttress against social breakdown, and Zeynep Bulutgil (2016), who focuses on the effect of cross-cutting cleavages on the likelihood of ethnic cleansing.

Wimmer, however, is unsatisfied with the explanatory power of voluntary organizations, public goods provision, and linguistic integration for successful nation-building. These may be sufficient, 
but they are not necessary mechanisms for nation-building. To identify these necessary conditions, he moves back through time to endogenize these mechanisms into older legacies of state capacity, especially "bureaucratic capacity and a uniform language" (12). Ultimately, for Wimmer, this older legacy of state capacity is an outcome of population density and topography. In particular, he highlights the importance of "high mountain ranges and deep valleys ... because state builders were more successful where peasants could not escape them by simply moving away" (16). In this sense, the theory is consistent with Jim Scott's argument, developed in The Art of Not Being Governed (2009). He tests this argument in Chapter 5, embarking on a herculean statistical effort. He resorts to instrumental variables to identify the exogenous effects of his explanatory variables: in particular, "average suitability for agriculture as an instrument for railway density (railways don't usually lead into a desert); the number of foreign Catholic priests and Protestant missionaries in 1923 for literacy rates after World War II (as priests and missionaries tried to teach colonial subjects to read and write); the number of past ethnonationalist wars fought before World War II for the density of voluntary organizations (since armed conflict destroys associational life); and the heterogeneity of agricultural suitability across the regions of a country for linguistic diversity" (105). However, as he describes in his own appendix (279), it is debatable whether these instruments have an effect on nation-building only through the relevant independent variables, a requirement for an instrument to be effective.

In Chapter 6, Wimmer employs data from representative surveys from 123 countries measuring citizens' pride in their country. Unsurprisingly, the findings are consistent with his expectations: "members of discriminated-against groups feel far less proud of their country and nation than do groups represented in the national government" (59). In Chapter 7, Wimmer challenges the negative relationship that economists have established between diversity and public goods provision, finding that a "lack of centralized states in the past left a legacy of both high diversity and a limited capacity of providing public goods in the present" (247). Finally, in Chapter 8, Wimmer discusses global trends that, in his view, are favorable for successful nation-building and discusses outliers from his statistical analysis. He then turns to third party nation-building in Afghanistan and arrives "at a more nuanced and less optimistic conclusion" (257) than for other parts of the world.

Let me now turn to some critical comments in the spirit of generating a debate. I will begin with a discussion of conceptualization, then move to the mechanisms, and conclude with a discussion of the logic of the main causal argument.

\section{Concepts}

Wimmer's conceptualization of successful nation-building is rather broad, including both political integration and national identification as two sides of the nation-building coin. It involves national identification, pride, precedence of the nation over other identity categories, and integration through political inclusion. His approach leads to conceptual stretching in some instances. For example, in the introduction Wimmer argues that "political equality between ethnic groups is a key defining element of nation-building [ . . . ] oppressing or even physically harming minority individuals shows that a nation-building project has failed-not that it is on the road to success" (6). This statement makes it clear that Wimmer's understanding of nation-building is based on a functional definition of nationality: political identification is the ultimate result of inclusive governing coalitions that are themselves the result of favorable conditions for state centralization in the past. However, if we understand nation-building as the process through which governing elites attempt to make the boundaries of the nation congruent to the boundaries of the state (Gellner 1983; Mylonas 2012) then a more complex picture emerges. More specifically, what form nationbuilding will take depends on what Rogers Smith (2003) has called the "constitutive story" of each nation-state. In other words, in a territorially defined nation-state that pursues nation-building, Wimmer's point about political equality between ethnic groups or oppression of minorities would resonate. Conversely, in an ethnoculturally defined nation-state, it would not be surprising if state 
elites oppose political equality and pursue forced assimilation or even exclusionary policies. These types of policies have led to successful nation-building in various countries, albeit involving terrible death tolls and suffering (Mylonas 2012; Bulutgil 2016). Some may even argue that the most successful nation-building variety has been that which either fully assimilated or excluded non-core groups altogether (Rae 2002, Marx 2005).

Beyond the conceptualization of nation-building, Wimmer makes a special effort to utilize the terms "indigenous" and "centralized" before the word "state" in order to distinguish these types of states from "externally imposed" and "failed states," respectively. These adjectives are intriguing, but they could have been unpacked or tested more in the book. For instance, some of the ethnopolitically inclusive regimes in certain countries have been externally imposed (either directly, as it happened with the Ohrid Agreement in North Macedonia, or indirectly, through conditionality principles in various parts of the world, as in Sub-Saharan Africa). In this vein, Wimmer's move in Chapter 8-from studying endogenous or indigenous nation-building around the world, to studying third party state building or "democracy promotion" in Afghanistan-is tricky. It also raises a broader question: why would externally imposed inclusive regimes have different effects than endogenously-produced ones? Wimmer suggests that "public goods provision by outsiders doesn't help in building the legitimacy of a national government nearly as much as when the government itself is in charge. It might even alienate the population and drive it into the arms of armed opposition groups such as the Taliban" (265). Is this conclusion based on the assumption that we are dealing with an information rich environment where the local population actually knows enough about the role of external actors? To put it differently, if an external actor supported a government covertly in its nation-building efforts, would success be more likely?

\section{Paired Comparisons and Mechanisms}

In terms of the more proximate mechanisms leading to successful nation-building-voluntary organizations, public goods provision, and linguistic integration-many readers will likely expect a clear "hierarchy" or relationship between them. While Wimmer clearly points out that none of the mechanisms he discusses are necessary for successful nation-building, he also makes it clear that each one is sufficient by itself. But when we examine some of the cases more closely, contradictions emerge. For instance, Russia is presented as an example of a failed nation-building attempt when compared to China, ${ }^{1}$ due to its multi-lingual fabric. In the Soviet Union, however, public goods provision improved, and efforts to include or co-opt local elites intensified. Why was public goods provision enough to lead to successful nation-building in linguistically heterogeneous Botswana but not in the USSR?

One way to reconcile this contradiction would be to highlight that the Russian Empire was multiethnic by design and never really pursued nation-building across the whole Empire. Similarly, the USSR's motto was "national in form, socialist in content" and was rather purposely divided into separate republics, structured as a federation of independent states with their titular groups, and so forth. To be sure, there were efforts to generate a supra-national Soviet identity and for linguistic Russification. But, Soviet policies also purposefully cultivated and institutionalized distinct identities in the various Soviet Republics. Thus, I wonder whether we should characterize this as a case of failed nation-building or as a case where nation-building was not fully implemented or, at times, not even attempted.

Another puzzle that flows from the China-Russia comparison has to do with the role of initial linguistic homogeneity. It is not clear if linguistic homogeneity is sufficient just at the elite level or if it must be manifest more broadly. In the Chinese case the role of the elites is central. When we turn to Russia, however, one could argue that non-core group elites were also fluent in Russian. This was even more so during the Soviet period. Even if Chinese elites were better able to communicate with each other than Russian elites, why is that? If the answer is that elites in the Chinese context understood themselves as Han irrespective of their dialect, but the elites of the Russian empire did 
not, then the exogenous variable is this sense of peoplehood or ethnic affinity. Once again, in the Russian context this could be the result of not trying to generate such a sense of peoplehood.

Turning to the mechanism of public goods provision, one wonders whether some public goods might be more likely to lead to national integration than others. For instance, mass schooling with national content would probably have a greater effect than other types of public goods (Darden and Mylonas 2016). Similarly, when it comes to the mechanism of civic associations, does it matter what type of associations are formed? For instance, what if the civic associations that are formed exclude certain parts of the population? In short, what about the dark side of social capital, when social ties and shared beliefs or norms are detrimental to certain individuals in a society or lead to corrupt practices (Portes and Landolt 2000)? Wimmer seems agnostic on this point. Finally, what is the relationship between the development of civic associations and industrialization? As Wimmer mentions, the Flemish-speaking rural hinterland of Belgium was not industrialized, but rural areas in central Switzerland experienced waterpower-driven industrialization (59). Could the variation in civic associations and/or in nation-buidling outcomes be the product of this divergence in the pattern of industrialization?

\section{The Logic of the Argument}

How can we account for cases with inherited levels of state centralization that did not adopt nationbuilding policies? For example, Burgundy or Great Moravia do not exist today. Conversely, what explains strong national identification and pride among members of stateless national movements, such as the Kurds? Are the Kurdish people who are motivated by Kurdish nationalism the result of some state centralization in the $19^{\text {th }}$ century or even earlier? If yes, why did some stateless nationalist movements survive while others did not? Miroslav Hroch's (2000) important book attempts to answer this puzzle in the European context. A potentially important omitted variable could be "world time" at the moment of independence. In other words, what were the expectations and norms about setting up your state at the time when the independence movement occurred? Relatedly, any such testing exercise necessarily privileges the contemporary state borders. In other words, Burgundy could yet re-emerge or the Kurdish nationalist movement subside. Similarly, cases that looked successful in the interwar years may no longer look successful today, such as Belgium or Czechoslovakia.

The most exogenous part of Wimmer's argument is that variation in topography and population density explain the success of initial state building efforts. But could there be an alternative argument that accounts for variation in initial state or nation-building efforts? Keith Darden and I (2016) have argued that the international geopolitical environment in which a state develops partially determines the extent of its linguistic commonality and its national cohesion. Specifically, we suggest that the presence of an external threat of territorial conquest, especially in the form of an externally-supported secession, is likely to lead governing elites to pursue nation-building strategies to generate national cohesion, often leading to the cultivation of a common national language through mass schooling and/or exclusionary policies. Comparing cases with similar levels of initial linguistic heterogeneity, state capacity, and development, but in different international environments, we find that states that did not face external threats to their territorial integrity were more likely to outsource education and other tools for constructing identity to missionaries or other groups, or to not invest in assimilation at all, leading to higher ethnic heterogeneity. Conversely, states developing in higher threat environments were more likely to invest in nation-building strategies to homogenize their populations. In other words, if Darden and I are correct, then there could be a spurious relationship. The presence of an external threat of territorial conquest, especially through a fifth column, provides governing elites with strong incentives to pursue state and nation-building strategies, which in turn generate linguistic homogeneity and national cohesion. Thus, our argument would account for both state centralization and linguistic homogeneity. The relationship between centralization and homogeneity could be partly or entirely produced by 
this external threat environment. Wimmer has not tested this argument in his statistical models, but instead categorized it as "faster moving" (20) compared to his own, which focuses on "tectonic shifts." I understand that it may be hard to code this variable in a satisfactory way in a panel dataset (though I hope he is interested in collaborating with us to test it), but a more direct discussion of this alternative path to successful nation-building would have been informative.

To be sure, part of this disagreement may result from the fact Darden and I are focusing on the onset of nation-building policies, or accounting for the variation in the form it takes in different contexts; while Wimmer is focusing on the success or failure of nation-building. What is key here, however, is that focusing on success or failure in a statistical context is tantamount to assuming that nation-building was attempted everywhere.

All in all, Wimmer has written an important book on the determinants of successful nationbuilding. Academics, practitioners, human rights activists, and policymakers interested in nationbuilding should read it. He has successfully reclaimed the term nation-building from those studying third party state-building or democracy promotion. His work crosses disciplinary boundaries and revitalizes the macro-sociological political modernization literature while convincingly highlighting the importance of political alliance structures for successful nation-building.

\section{Note}

1 According to Wimmer, China and Russia are comparable since they "form their own centers of civilizational gravity, contain enormous, polyglot populations, and were never subjected to Western colonial rule." (p. 12) That said, from a Chinese nationalism perspective, things may look different given the "century of humiliation," the period of foreign intervention and subjugation of the Chinese Empire that began in 1839 and continued into the $20^{\text {th }}$ century.

\section{References}

Bulutgil, Zeynep. 2016. The Roots of ethnic cleansing in Europe. Cambridge University Press.

Darden, Keith, and Harris Mylonas. 2016. "Threats to territorial integrity, national mass schooling, and linguistic commonality." Comparative Political Studies 49, no. 11: 1446-1479.

Deutsch, Karl W. 1953. Nationalism and Social Communication: An Inquiry Into the Foundations of Nationality. MIT and Wiley, New York.

Gellner, Ernest. 1983. Nations and nationalism. Cornell University Press.

Hroch, Miroslav. 2000 [1968]. Social preconditions of national revival in Europe: a comparative analysis of the social composition of patriotic groups among the smaller European nations. Columbia University Press.

Marx, Anthony W. 2005. Faith in nation: exclusionary origins of nationalism. Oxford: Oxford University Press.

Mylonas, Harris. 2012. The Politics of Nation-Building: Making Co-Nationals, Refugees, and Minorities. New York, NY: Cambridge University Press.

Portes, Alejandro, and Patricia Landolt. 2000. “Social Capital: Promise and Pitfalls of Its Role in Development.” Journal of Latin American Studies 32, no. 2: 529-47.

Rae, Heather. 2002. State Identities and the Homogenisation of Peoples. Cambridge: Cambridge University Press.

Scott, James. 2009. The Art of Not Being Governed: An Anarchist History of Upland Southeast Asia. Yale University Press.

Smith, Rogers M. 2003. Stories of peoplehood: The politics and morals of political membership. Cambridge University Press.

Straus, Scott. 2015. Making and unmaking nations: War, leadership, and genocide in modern Africa. Cornell University Press.

Cite this article: Mylonas, H. 2022. The Determinants of Successful Nation-building: Macro-sociological Political Modernization and Political Alliance Structures. Nationalities Papers 50: 185-189, doi:10.1017/nps.2020.97 